FOLIA POMERANAE UNIVERSITATIS TECHNOLOGIAE STETINENSIS

Folia Pomer. Univ. Technol. Stetin., Oeconomica 2018, 347(93)4, 57-68

Joanna PERZYŃSKA

\title{
ZASTOSOWANIE SZTUCZNYCH SIECI NEURONOWYCH DO HYBRYDOWEGO MODELOWANIA I PROGNOZOWANIA SZEREGÓW CZASOWYCH
}

\author{
APPLICATION OF ARTIFICIAL NEURAL NETWORK TO HYBRID MODELLING \\ AND FORECASTING OF TIME SERIES
}

Katedra Zastosowań Matematyki w Ekonomii, Zachodniopomorski Uniwersytet Technologiczny w Szczecinie, ul. Klemensa Janickiego 31, 71-270 Szczecin, ORCID: 0000-0002-7182-2381

e-mail: joanna.perzynska@zut.edu.pl

\begin{abstract}
Summary. In the paper, the author presents the hybrid method of time series modelling using artificial neural networks. The illustration of theoretical considerations is the empirical example, in which models and forecasts are determined for microeconomic variable with trend and seasonal fluctuations with high intensity. In the first stage of the research, patterns in time series are identified using the self-organizing Kohonen maps. Next, a modification of the pattern identification method is applied. Based on it, fragments of time series are extracted, then models of multilayer perceptrons are built. In the last stage of the research, forecasts are determined, their quality is assessed on the basis of average ex-post errors. The research confirms the usefulness of hybrid neural models in time series forecasting.
\end{abstract}

Słowa kluczowe: perceptrony wielowarstwowe, samoorganizujące się sieci Kohonena, szeregi czasowe, sztuczne sieci neuronowe, wzorce.

Key words: artificial neural network, Kohonen self-organizing maps, multilayer perceptrons, time series, pattern.

\section{WSTĘP}

Szereg czasowy jest złożeniem wielu różnych składowych będących efektem oddziaływań na zjawisko zarówno stałych czynników, jak i przyczyn ubocznych. Dekompozycję szeregu na główne składowe systematyczne - trend (lub przeciętny poziom) i wahania sezonowe można przeprowadzić, budując klasyczne modele szeregu czasowego. Wyodrębnienie składowych o różnych częstotliwościach wiąże się ze stosowaniem bardziej zaawansowanych technik.

W szeregu czasowym można również wyróżnić tzw. wzorce (lub formacje), które są jego fragmentami charakteryzującymi się podobnymi własnościami. Lula (2001) zaproponował hybrydowe podejście do modelowania szeregu zawierającego wzorce, oparte na dwóch rodzajach sztucznych sieci neuronowych. Do identyfikacji wzorców wykorzystuje się wówczas samoorganizujące się sieci Kohonena - sztuczne sieci neuronowe realizujące uczenie bez nauczyciela. Następnie dla każdej z wyznaczonych formacji buduje się odrębne modele perceptronów wielowarstwowych - sieci jednokierunkowych uczonych z nauczycielem. 
Celem przeprowadzonych badań empirycznych, których wyniki przedstawiono w niniejszym artykule, była budowa hybrydowych modeli szeregu czasowego przedstawiającego zmienną mikroekonomiczną oraz wyznaczenie na ich podstawie prognoz ex post. W toku badań empirycznych zweryfikowano hipotezę zakładającą, że skonstruowane hybrydowe modele neuronowe mogą być użytecznym narzędziem prognozowania szeregów czasowych.

\section{METODY}

Sztuczne sieci neuronowe, odwzorowujące jedynie podstawowe procesy zachodzące w mózgu człowieka, są systemem połączonych ze sobą sztucznych neuronów - elementów przetwarzających dane. Dane z zewnątrz wprowadzane są do sieci przez neurony warstwy wejściowej, skąd (połączeniami o określonych wagach) przekazywane są do neuronów kolejnej warstwy, w której odbywa się ich przetwarzanie. Przetwarzanie polega na agregacji wartości wejściowych w pojedynczą wartość (tzw. łączne pobudzenie neuronu), która następnie przekształcana jest przez funkcję aktywacji. Wyznaczone w każdym neuronie wartości przekazywane są do kolejnych warstw (jeśli takie istnieją) lub stanowią wartości wyjściowe sieci. W zależności od sposobu połączeń neuronów można wyróżnić sieci: jednokierunkowe, radialne, rekurencyjne i komórkowe. Pierwsze trzy typy sieci służą głównie do aproksymacji, predykcji i optymalizacji, natomiast sieci komórkowe wykorzystuje się do problemów związanych z bezwzorcową klasyfikacją danych.

Sieci jednokierunkowe (tzw. perceptrony wielowarstwowe - MultiLayer Perceptron) zbudowane są z co najmniej dwóch warstw sztucznych neuronów - wejściowej i wyjściowej; mogą w nich również występować warstwy ukryte, do których użytkownik sieci nie ma bezpośredniego dostępu. Łączne pobudzenie neuronów w perceptronach wyznaczane jest jako ważona suma ich wartości wejściowych, przy czym wykorzystywane funkcje aktywacji są zazwyczaj funkcjami nieliniowymi. Pomiędzy neuronami brakuje sprzężeń zwrotnych sygnały przepływają w nich tylko w jednym kierunku - od wejść do wyjść. Wagi połączeń między neuronami wyznaczane są w procesie uczenia - jest to tzw. uczenie z nauczycielem, w którym prezentuje się sieci wzorcowe wartości wyjściowe i wejściowe. Sieć tak modyfikuje wagi, aby mogła uzyskać zgodność jej wartości wyjściowych z wzorcowymi danymi wyjściowymi. Szczegółowy opis algorytmów stosowanych w uczeniu z nauczycielem można znaleźć w pracach Osowskiego (1996) i Tadeusiewicza $(1993,1998)$.

Za pomocą perceptronów wielowarstwowych można wyznaczać prognozy szeregu czasowego. Jako próbki uczące wykorzystuje się wówczas podzbiory zawierające obserwacje szeregu i jego wartości opóźnione. Można również wcześniej dokonać dekompozycji szeregu czasowego na składowe systematyczne (trend i wahania sezonowe) i budować odrębne modele dla każdej z nich (por. Perzyńska 2018). Wyznaczenie prognoz wymaga wówczas zagregowania wyników.

Sieci komórkowe mają regularną strukturę - pomiędzy neuronami z najbliższego sąsiedztwa występują wzajemne sprzężenia. Najczęściej stosowaną siecią komórkową jest samoorganizująca się sieć Kohonena (Self-Organizing Map), która zbudowana jest z dwóch warstw - wejściowej i wyjściowej. Neurony warstwy wyjściowej rozmieszczone są w przestrzeni, tworząc mapę topologiczną; przedstawiane są zazwyczaj jako węzły dwuwymiarowej siatki 
o kwadratowych oczkach. Siatka ta w procesie uczenia może być dowolnie zginana i wykrzywiana w celu zachowania oryginalnej struktury (zwłaszcza podobieństw) danych wejściowych. Budowa wyjściowej warstwy sieci Kohonena zainspirowana została budową kory mózgowej, będącej mapą topologiczną odzwierciedlającą złożoną konstrukcję całego ciała człowieka (Tadeusiewicz 1993, 1998).

Neurony wyjściowej warstwy sieci Kohonena to neurony radialne, w nich odbywa się zasadnicze przetwarzanie danych. Neuron radialny definiuje się poprzez podanie współrzędnych jego centrum oraz promienia. Łączne pobudzenie neuronu radialnego wyznaczane jest jako wartość wybranej miary odległości wektora wartości wejściowych oraz wektora wag (współrzędnych centrum) danego neuronu; najczęściej stosuje się odległość euklidesową. Łączne pobudzenie neuronu przekształcane jest przez funkcję aktywacji, która w sieci Kohonena jest funkcją sąsiedztwa (prostokątnego lub gaussowskiego). Wyznaczona w ten sposób wartość wyjściowa neuronu radialnego jest tym większa, im mniejsza jest odległość wektora jego wag od wektora wartości wejściowych. Neuron o największej wartości wyjściowej zostaje neuronem zwycięskim, który podlega uczeniu (Tadeusiewicz 1993, 1998).

Sieć Kohonena jest tzw. siecią samoorganizującą, czyli uczoną bez nauczyciela - nie przedstawia się jej wzorcowych wartości wejściowych, sama uczy się rozpoznawać wspólne cechy wartości wejściowych i grupować je w odpowiednie klasy reprezentowane przez wyjścia sieci. Jej uczenie odbywa się na podstawie iteracyjnego algorytmu Kohonena wykorzystującego regułę „zwycięzca bierze wszystko”. Po prezentacji przypadków uczących ze zbioru dostępnych danych wartości wag neuronu zwycięskiego są tak modyfikowane, aby mogły przybliżać je do wartości wejściowych sieci. Modyfikowane są również wagi neuronów z sąsiedztwa neuronu zwycięskiego. Zmiany wag neuronu zwycięskiego i jego sąsiadów odbywają się w tym samym kierunku, jednak wraz ze wzrostem odległości poszczególnych neuronów od zwycięzcy mają coraz mniejsze wartości. Wraz z prezentacją kolejnych przypadków uczących zmniejszany jest promień sąsiedztwa, powodując, że należy do niego coraz mniej neuronów. W końcowym etapie sąsiedztwo ma prawie zerowy zasięg i obejmuje już tylko neuron zwycięski. Zmniejszanie sąsiedztwa ma na celu doskonalenie położenia neuronów na mapie topologicznej w taki sposób, aby powstały wyraźne skupienia rozpoznające klasy podobnych sygnałów wejściowych.

Sieci samoorganizujące się są wykorzystywane do zadań klasyfikacji dla danych przekrojowych. Lula (2001) zaproponował ich odmienne zastosowanie - w hybrydowej metodzie analizy szeregów czasowych. W takim przypadku zmiennymi wejściowymi sieci Kohonena mogą być opóźnione wartości szeregu, a także wartości innych zmiennych oraz wybranych mierników charakteryzujących kolejne obserwacje szeregu czasowego. Nauczona sieć dokonuje podziału szeregu na klasy będące wzorcami, czyli fragmentami o podobnych własnościach. Etap podziału szeregu czasowego na klasy może być wstępem do jego modelowania i prognozowania - Lula proponuje dalej, aby dla każdej z formacji budować odrębne modele perceptronów wielowarstwowych.

W niniejszym artykule zastosowano zaproponowane przez Lulę podejście do identyfikacji wzorców, ponadto przedstawiono jego autorską modyfikację opartą na wykorzystaniu wahań sezonowych występujących w szeregu czasowym dla danych miesięcznych - zmiennymi wejściowymi sieci Kohonena są wówczas wartości szeregu z poszczególnych lat. Nauczona sieć dokonuje podziału na regularne wzorce, w których obserwacje z tych samych miesięcy w kolejnych latach należą zawsze do tej samej klasy. 


\section{MATERIA}

W przeprowadzonych badaniach empirycznych modelowaniu i prognozowaniu poddano przychody ze sprzedaży betonu komórkowego (SB) w przedsiębiorstwie X (w tys. PLN). Jako zmienną wejściową sieci Kohonena wykorzystano wielkość produkcji betonu komórkowego (PB) w przedsiębiorstwie $X\left(\mathrm{w} \mathrm{m}^{3}\right)$. Pomiędzy zmiennymi istnieje silna korelacja dodatnia; współczynnik korelacji liniowej wynosi 0,83 . Szeregi czasowe wartości obu zmiennych obejmują 60 miesięcy; ich kształtowanie się przedstawiono na ryc. 1 i 2.

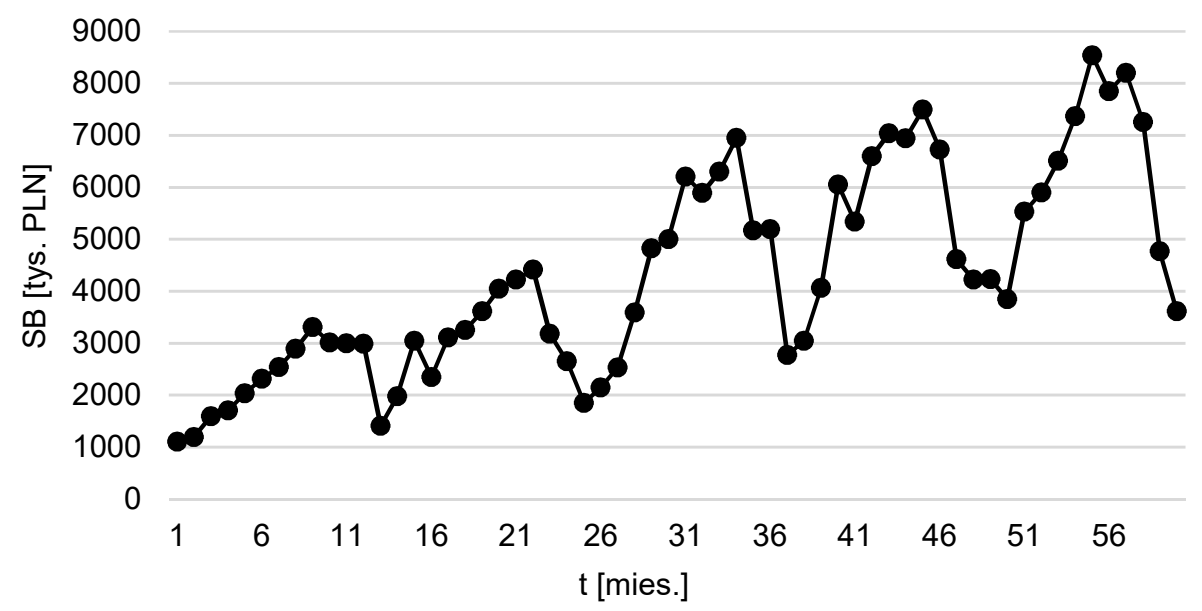

Ryc. 1. Kształtowanie się zmiennej SB

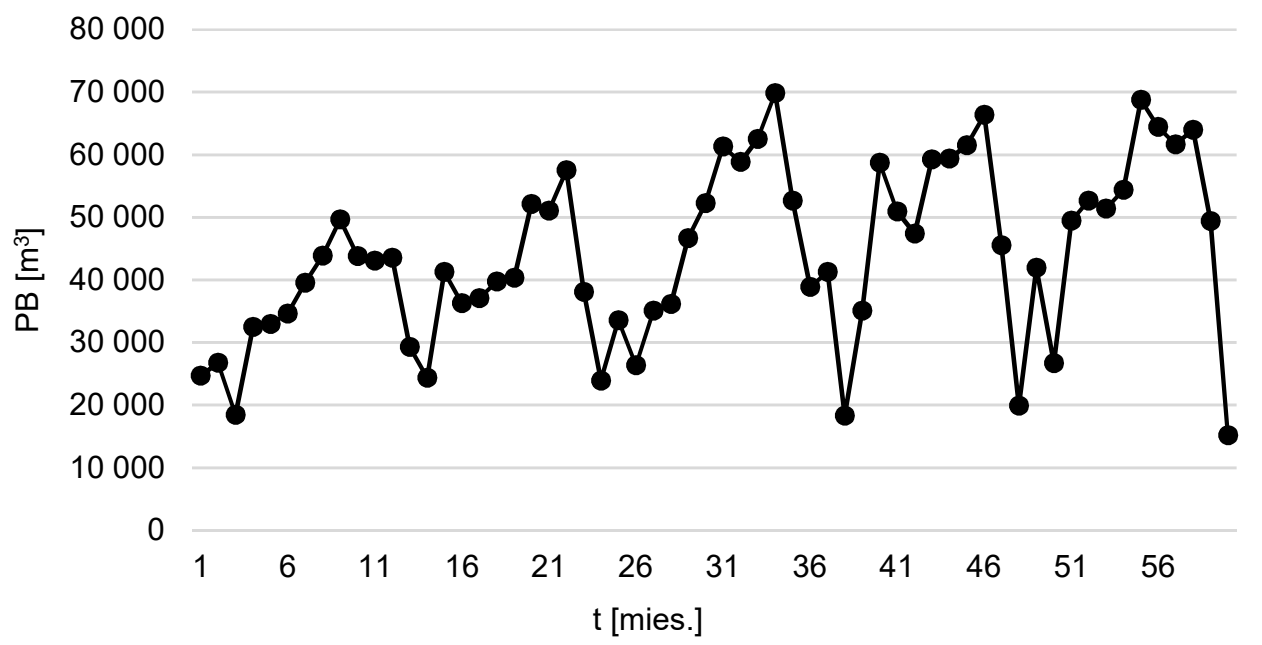

Ryc. 2. Kształtowanie się zmiennej PB

Obie zmienne charakteryzują się występowaniem trendu oraz wahań sezonowych. W tabeli 1 zestawiono oceny ich wskaźników sezonowości z okresów miesięcznych.

Zmienne SB i PB charakteryzują się występowaniem wahań sezonowych o silnym natężeniu - różnice pomiędzy maksymalną i minimalną wartością ocen wskaźników sezonowości są dla nich zbliżone i wynoszą odpowiednio 81,14 pp. oraz 81,38 pp. 
Tabela 1. Oceny wskaźników sezonowości [\%]

\begin{tabular}{|c|c|c|}
\hline Miesiąc & Zmienna SB & Zmienna PB \\
\hline I & 78,87 & 51,03 \\
\hline II & 52,97 & 60,24 \\
\hline III & 84,21 & 79,75 \\
\hline IV & 95,86 & 90,29 \\
\hline V & 98,19 & 101,93 \\
\hline VI & 102,55 & 111,35 \\
\hline VII & 112,35 & 118,64 \\
\hline VIII & 124,16 & 124,29 \\
\hline IX & 130,53 & 132,40 \\
\hline X & 134,10 & 131,45 \\
\hline XI & 103,84 & 103,42 \\
\hline XII & 82,37 & 95,21 \\
\hline
\end{tabular}

Na potrzeby badań empirycznych każdy z szeregów czasowych podzielono na dwie części pierwsza, obejmująca 48 początkowych wartości $(t=1,2, \ldots, 48)$, posłużyła do identyfikacji wzorców w szeregu wartości zmiennej SB i budowy modeli perceptronowych, natomiast druga część szeregów ( $\mathrm{t}=49,50, \ldots, 60$ ) wykorzystana została do budowy i empirycznej weryfikacji prognoz.

\section{WYNIKI}

Budowę modeli sztucznych sieci neuronowych przeprowadzono w programie Statistica PL. W pierwszym etapie badań empirycznych zbudowano sieci Kohonena i przeprowadzono ich uczenie. Rozpatrzono kilka wariantów sieci różniących się rozmiarami warstwy wyjściowej, które podczas konstrukcji należy ustalać arbitralnie. Jako zmienną wejściową sieci wykorzystano wartości szeregu czasowego $(t=1,2, \ldots, 48)$ zmiennej PB silnie skorelowanej z modelowaną zmienną SB. Kolejne obserwacje zmiennych wejściowych podzielono losowo na trzy podzbiory: uczący, testowy i walidacyjny, które miały zapewnić prawidłowe wytrenowanie sieci. Dane wejściowe poddano preprocessingowi polegającemu na normalizacji ich wartości. Uczenie rozpoczęto losową inicjalizacją wag; obejmowało ono 1000 epok (prezentacji próbek uczących). Sieci uczone były bez nauczyciela; podczas tego procesu same modyfikowały początkowe wartości wag. Oceny skonstruowanych sieci Kohonena dokonano na podstawie uniwersalnych mierników jakości wyznaczonych jako błędy średnie kwadratowe. Spośród wielu nauczonych sieci wybrano kilka najlepszych (o najmniejszych różnicach błędów osiągniętych w zbiorach uczącym, testowym i walidacyjnym); ich charakterystyki przedstawiono w tab. 2.

Tabela 2. Charakterystyki wybranych sieci Kohonena

\begin{tabular}{|l|c|c|c|c|}
\hline Numer sieci & $\begin{array}{c}\text { Rozmiar warstwy } \\
\text { wyjściowej }\end{array}$ & $\begin{array}{c}\text { Błąd } \\
\text { uczenia }\end{array}$ & $\begin{array}{c}\text { Błąd } \\
\text { testowania }\end{array}$ & $\begin{array}{c}\text { Błąd } \\
\text { walidacji }\end{array}$ \\
\hline SOM1 & $1 \times 2$ & 0,0214 & 0,0153 & 0,0163 \\
\hline SOM2 & $1 \times 3$ & 0,0084 & 0,0100 & 0,0114 \\
\hline SOM3 & $2 \times 2$ & 0,0186 & 0,0202 & 0,0175 \\
\hline SOM4 & $2 \times 3$ & 0,0141 & 0,0196 & 0,0149 \\
\hline SOM5 & $3 \times 3$ & 0,0014 & 0,0035 & 0,0042 \\
\hline SOM6 & $3 \times 4$ & 0,0010 & 0,0025 & 0,0036 \\
\hline
\end{tabular}


Nauczone sieci Kohonena zastosowano do identyfikacji wzorców w szeregu czasowym wartości zmiennej $\mathrm{SB}$ dla $\mathrm{t}=1,2, \ldots, 48$. Zauważono, że niezależnie od wyboru zmiennych wejściowych (PB lub SB), dla sieci o takich samych rozmiarach warstwy wyjściowej, obserwacje o tych samych numerach zaliczone zostały do identycznych klas. Wynika to z silnej dodatniej korelacji obu zmiennych i świadczy o poprawnym wyborze zmiennej wejściowej podczas uczenia sieci. Wzorce wyodrębnione na podstawie dwóch pierwszych sieci samoorganizujących (o dwóch i trzech neuronach wyjściowych), dla $t=1,2, \ldots, 48$, przedstawiono na ryc. 3 i 4.

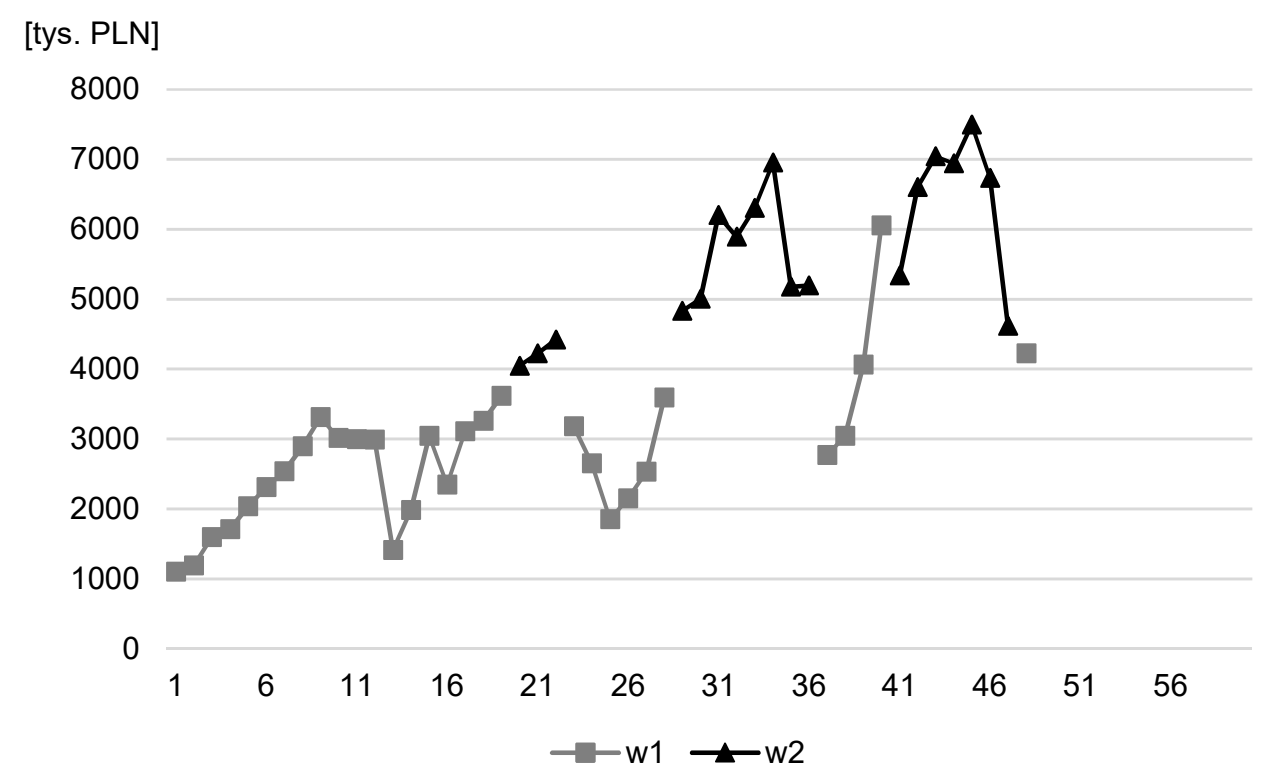

Ryc. 3. Wzorce zmiennej SB wyznaczone na podstawie sieci SOM1

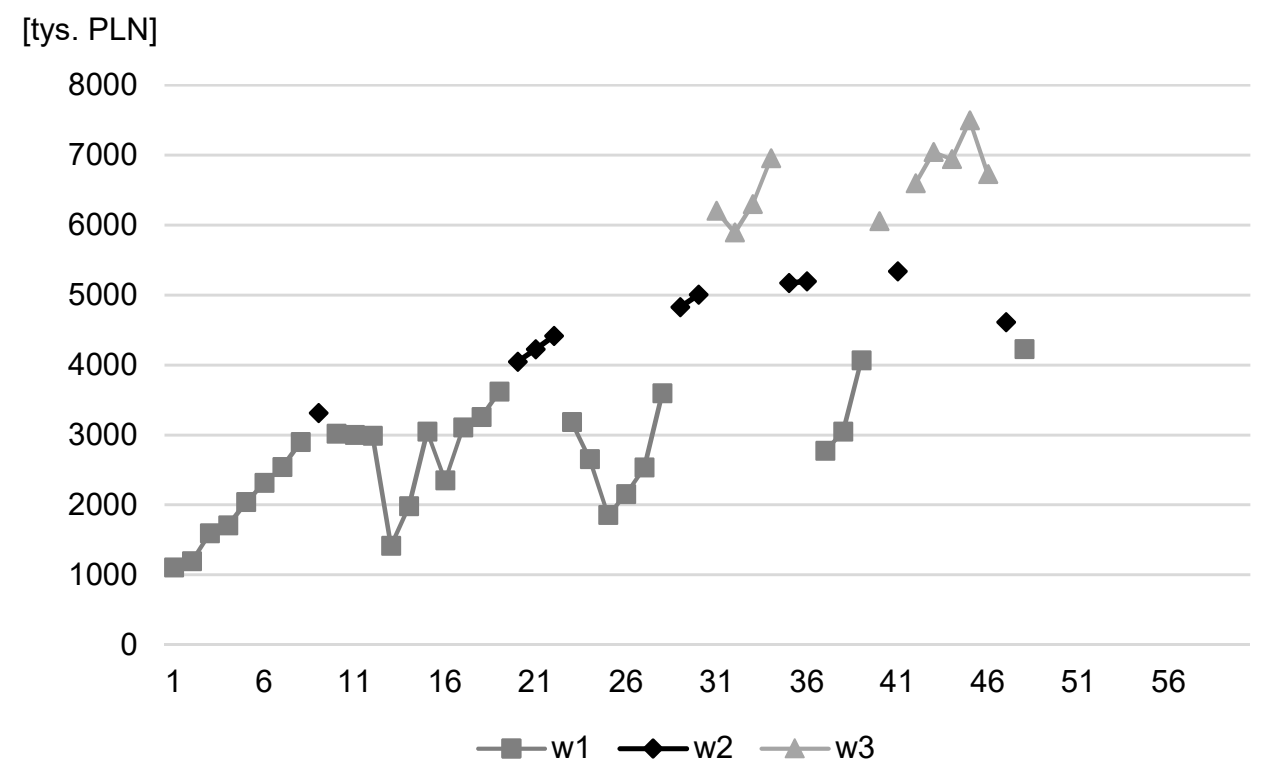

Ryc. 4. Wzorce zmiennej SB wyznaczone na podstawie sieci SOM2

Analizując wykres przedstawiony na ryc. 3, można zauważyć, że w przypadku podziału szeregu wartości zmiennej SB na dwie klasy (będące wzorcami) na jego początku występują obserwacje należące wyłącznie do jednej z nich. Dopiero począwszy od 21. miesiąca (czyli 
pod koniec drugiego roku) w kształtowaniu wielkości przychodów ze sprzedaży betonu można wyróżnić dwie różne formacje - pierwsza z nich obejmuje obserwacje $z$ tej samej klasy co początek szeregu i zawierają się w niej minima sezonowe, druga zaś obejmuje głównie górną część wykresu zmiennej (powyżej 4000 tys. PLN), z maksimami sezonowymi z dwóch ostatnich lat.

W przypadku podziału szeregu wartości zmiennej SB na trzy klasy (przedstawionego na ryc. 4), wyróżnione wcześniej dwie formacje uległy dodatkowemu podziałowi - pomiędzy dwoma wzorcami zawierającymi głównie minima i maksima sezonowe pojawiła się trzecia formacja o pośrednich wartościach układających się wzdłuż nieliniowej funkcji trendu. Funkcja ta początkowo jest rosnąca, zaś w przypadku jej ostatniej wartości (o numerze 47) następuje zmiana monotoniczności.

Wraz ze zwiększaniem liczby neuronów w warstwie wyjściowej sieci Kohonena następowało dalsze różnicowanie istniejących klas na mniejsze podzbiory. Dla ostatniej wybranej sieci SOM6 otrzymano 12 wzorców wartości szeregu czasowego zmiennej SB; macierz numerów obserwacji $(\mathrm{t}=1,2, \ldots, 48)$ do nich należących przedstawiono w tab.3.

Tabela 3. Macierz numerów wartości zmiennej SB dla wzorców wyznaczonych na podstawie sieci SOM6

\begin{tabular}{|c|l|l|l|l|}
\hline \multirow{2}{*}{$\begin{array}{c}\text { Numer wiersza } \\
\text { warstwy wyjściowej }\end{array}$} & \multicolumn{4}{|c|}{ Numer kolumny warstwy wyjściowej } \\
\cline { 2 - 5 } & \multicolumn{1}{|c|}{1} & \multicolumn{1}{|c|}{2} & \multicolumn{1}{c|}{3} & \multicolumn{1}{c|}{4} \\
\hline 1 & $1,2,3,13$ & $7,24,27,37$ & $35,36,41$ & $34,42,43,44,45,46$ \\
\hline 2 & $4,5,6,11,14,16$ & $\begin{array}{l}8,10,15,17,25, \\
26,29,30,38\end{array}$ & 47 & $31,32,33,40$ \\
\hline 3 & 12 & $9,18,23$ & 19,28 & $20,21,22,39,48$ \\
\hline
\end{tabular}

Analizując informacje zawarte $w$ tab. 3, można zauważyć dwie klasy znajdujące się w macierzy na pozycjach o współrzędnych kartezjańskich $(3,1)$ i $(2,3)$, do których należy tylko po jednej obserwacji. Są to wartości szeregu różniące się od innych pod względem wyznaczonej przez sieć wartości funkcji sąsiedztwa, co sugeruje, że mogą być one potraktowane też jako nietypowe wartości szeregu: dla 12. obserwacji następuje wzrost przychodów ze sprzedaży w porównaniu z poprzednim miesiącem, później zaś przychody ponownie maleją; natomiast 47. wartość zmiennej SB znacznie mniejsza od wartości w poprzednim okresie, sugeruje zmianę tendencji ze wzrostowej na spadkową, co widać było na ryc. 4.

W kolejnym etapie badań dla wyodrębnionych wzorców powinny zostać zbudowane i wytrenowane oddzielne perceptrony wielowarstwowe. Było to jednak niemożliwe, gdyż sekwencja wyodrębnionych fragmentów szeregu nie powtarzała się zbyt regularnie. Ponadto w ramach każdej z frakcji jej części miały różną długość, co nie pozwoliło na właściwe określenie wzorcowych wartości wejściowych i wyjściowych sieci niezbędnych do przeprowadzenia uczenia.

W związku z powyższym zmodyfikowano przedstawioną przez Lulę metodę i jeszcze raz przeprowadzono identyfikację wzorców na podstawie sieci Kohonena. Zaproponowano nowe podejście, opierające się na wykorzystaniu wahań sezonowych występujących w szeregu czasowym dla danych miesięcznych, co pozwala na zaliczenie obserwacji z tych samych miesięcy do tej samej klasy. Zmiennymi wejściowymi sieci Kohonena są wówczas wartości szeregu z poszczególnych lat; każda zawiera 12 obserwacji z kolejnych miesięcy. Nauczona sieć klasyfikuje obserwacje do z góry zadanej liczby klas stanowiących wzorce. Postępując w opisany sposób, dokonano podziału szeregu wartości zmiennej SB na dwie i trzy klasy. 
Charakterystyki skonstruowanych samoorganizujących się sieci Kohonena zestawiono w tab. 4. W tabeli 5 zestawiono współrzędne kartezjańskie zwycięskich neuronów na topologicznej mapie wyjściowej warstwy skonstruowanych sieci. Neurony o tej samej pozycji w macierzy wyznaczają formacje, do których można zaliczyć wartości szeregu z poszczególnych miesięcy.

Tabela 4. Charakterystyki sieci Kohonena dla zmodyfikowanej metody identyfikacji wzorców

\begin{tabular}{|l|c|c|c|c|}
\hline \multicolumn{1}{|c|}{ Numer sieci } & $\begin{array}{c}\text { Rozmiar warstwy } \\
\text { wyjściowej }\end{array}$ & $\begin{array}{c}\text { Błąd } \\
\text { uczenia }\end{array}$ & $\begin{array}{c}\text { Błąd } \\
\text { testowania }\end{array}$ & $\begin{array}{c}\text { Błąd } \\
\text { walidacji }\end{array}$ \\
\hline SOM7 & $1 \times 2$ & 0,1819 & 0,2172 & 0,0530 \\
\hline SOM8 & $1 \times 3$ & 0,0893 & 0,1089 & 0,1022 \\
\hline
\end{tabular}

Tabela 5. Współrzędne zwycięskich neuronów wyjściowej warstwy sieci Kohonena

\begin{tabular}{|c|c|c|}
\hline Miesiąc & SOM7 & SOM8 \\
\hline I & $(1,1)$ & $(1,1)$ \\
\hline II & $(1,1)$ & $(1,1)$ \\
\hline III & $(1,1)$ & $(1,1)$ \\
\hline IV & $(1,1)$ & $(1,2)$ \\
\hline V & $(1,1)$ & $(1,2)$ \\
\hline VI & $(1,2)$ & $(1,3)$ \\
\hline VII & $(1,2)$ & $(1,3)$ \\
\hline VIII & $(1,2)$ & $(1,3)$ \\
\hline IX & $(1,2)$ & $(1,3)$ \\
\hline$X$ & $(1,2)$ & $(1,2)$ \\
\hline XI & $(1,2)$ & $(1,2)$ \\
\hline XII & $(1,1)$ & \\
\hline
\end{tabular}

Analizując informacje zestawione w tab. 4, można zauważyć, że w przypadku wyodrębnienia dwóch wzorców w szeregu wartości zmiennej SB (sieć SOM7) do jednego z nich zaliczono kolejnych sześć obserwacji w każdym roku (od czerwca do listopada); pozostałe wartości należą do drugiej frakcji. Podział ten jest zbliżony do podziału na dwa półrocza w roku (przesunięta jest jedna obserwacja z każdego półrocza) i wykazuje pewne podobieństwo do hierarchicznych modeli szeregu czasowego. Wzorce wyznaczone na podstawie sieci SOM7 i SOM8, dla $\mathrm{t}=1,2, \ldots, 48$, przedstawiono graficznie na ryc. 5 i 6 .

[tys. PLN]

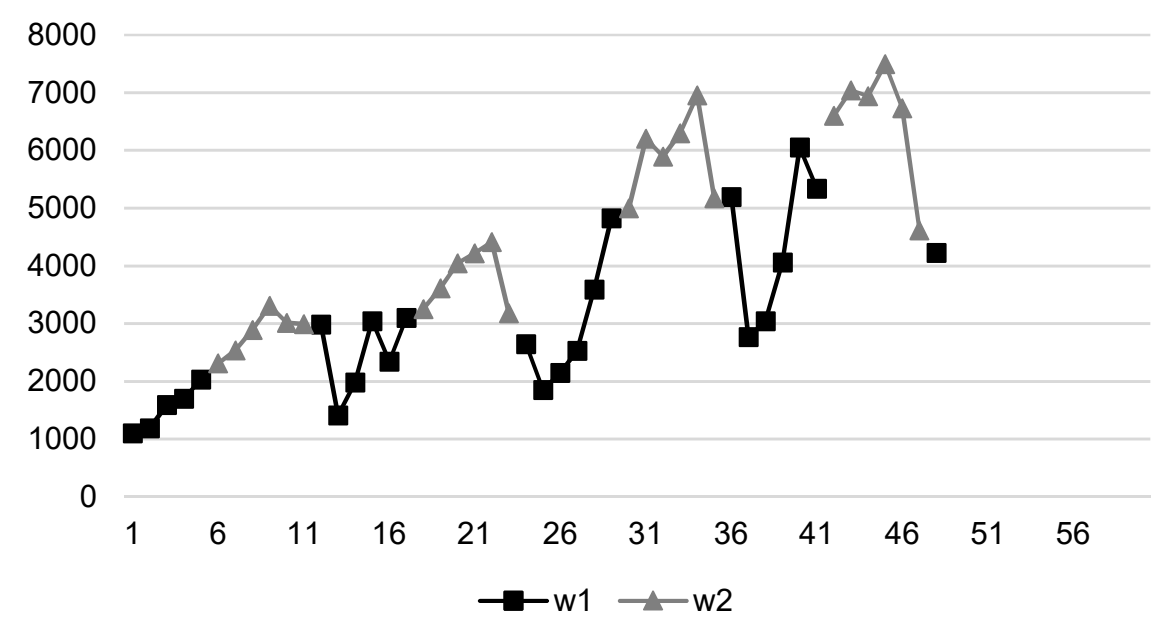

Ryc. 5. Wzorce zmiennej SB wyznaczone na podstawie sieci SOM7 
[tys. PLN]

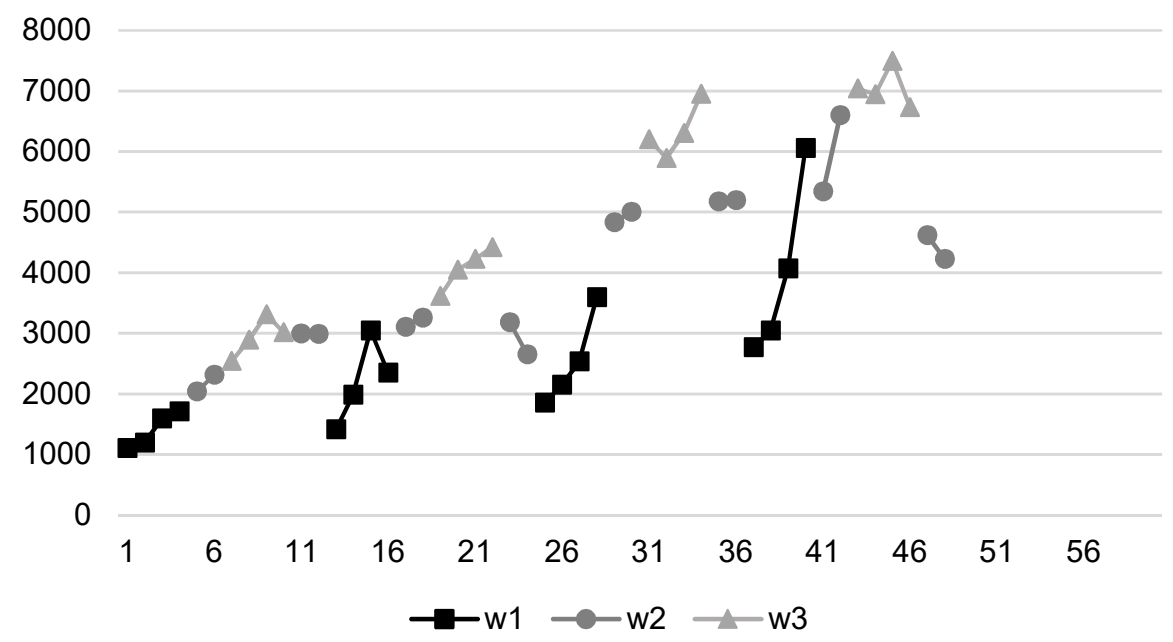

Ryc. 6. Wzorce zmiennej SB wyznaczone na podstawie sieci SOM8

W ostatnim etapie badań dla każdego ze wzorców wyodrębnionych, na podstawie samoorganizujących się sieci Kohonena SOM7 i SOM8, zbudowano indywidualne modele perceptronów wielowarstwowych - dla frakcji wyodrębnionych na podstawie sieci SOM7 były to dwa perceptrony MLP1, oznaczone dalej odpowiednio numerami wzorców w1 i w2, a dla wzorców otrzymanych na podstawie sieci SOM8 - trzy perceptrony MLP2, oznaczone dodatkowo numerami w1, w2, w3. Sieci uczone były z nauczycielem, prezentowano im próbki uczące składające się z wzorcowych wartości wyjściowych i wejściowych, którymi były odpowiednio wartości szeregu zmiennej SB zaliczone do danej frakcji oraz opóźnione wartości zmiennej SB z tej samej frakcji.

W celach porównawczych zbudowano również najprostszy model perceptronowy dla szeregu wartości zmiennej SB z pierwszych 48 miesięcy, bez podziału na frakcje (MLP3). Jego wzorcowymi wartościami wyjściowymi i wejściowymi były wartości szeregu i wartości opóźnione.

Skonstruowano i wytrenowano wiele perceptronów różniących się liczbą warstw ukrytych; spośród nich wybrano po jednej sieci o najmniejszych błędach. Charakterystyki otrzymanych sieci zestawiono w tab. 6.

Tabela 6. Charakterystyki wybranych perceptronów wielowarstwowych

\begin{tabular}{|l|c|c|c|c|}
\hline \multicolumn{1}{|c|}{ Numer sieci } & $\begin{array}{c}\text { Liczba } \\
\text { warstw ukrytych }\end{array}$ & $\begin{array}{c}\text { Błąd } \\
\text { uczenia }\end{array}$ & $\begin{array}{c}\text { Błąd } \\
\text { testowania }\end{array}$ & $\begin{array}{c}\text { Błąd } \\
\text { walidacji }\end{array}$ \\
\hline MLP1-w1 & 2 & 0,1332 & 0,2563 & 0,1567 \\
\hline MLP1-w2 & 3 & 0,1734 & 0,1028 & 0,1476 \\
\hline MLP2-w1 & 2 & 0,0681 & 0,1225 & 0,0754 \\
\hline MLP2-w2 & 2 & 0,0832 & 0,0569 & 0,1023 \\
\hline MLP2-w3 & 3 & 0,0923 & 0,0425 & 0,0877 \\
\hline MLP3 & 4 & 0,2435 & 0,2976 & 0,3129 \\
\hline
\end{tabular}

Na podstawie zbudowanych modeli perceptronów wielowarstwowych wyznaczono prognozy zmiennej SB dla ostatnich 12 miesięcy $(t=49,50, \ldots, 60)$. W przypadku wszystkich wariantów perceptronów MLP1 i MLP2 trzeba było jeszcze dodatkowo dokonać agregacji wyników otrzymanych dla poszczególnych wzorców. Wartości wyznaczonych prognoz przedstawiono graficznie na ryc. 7-9. 


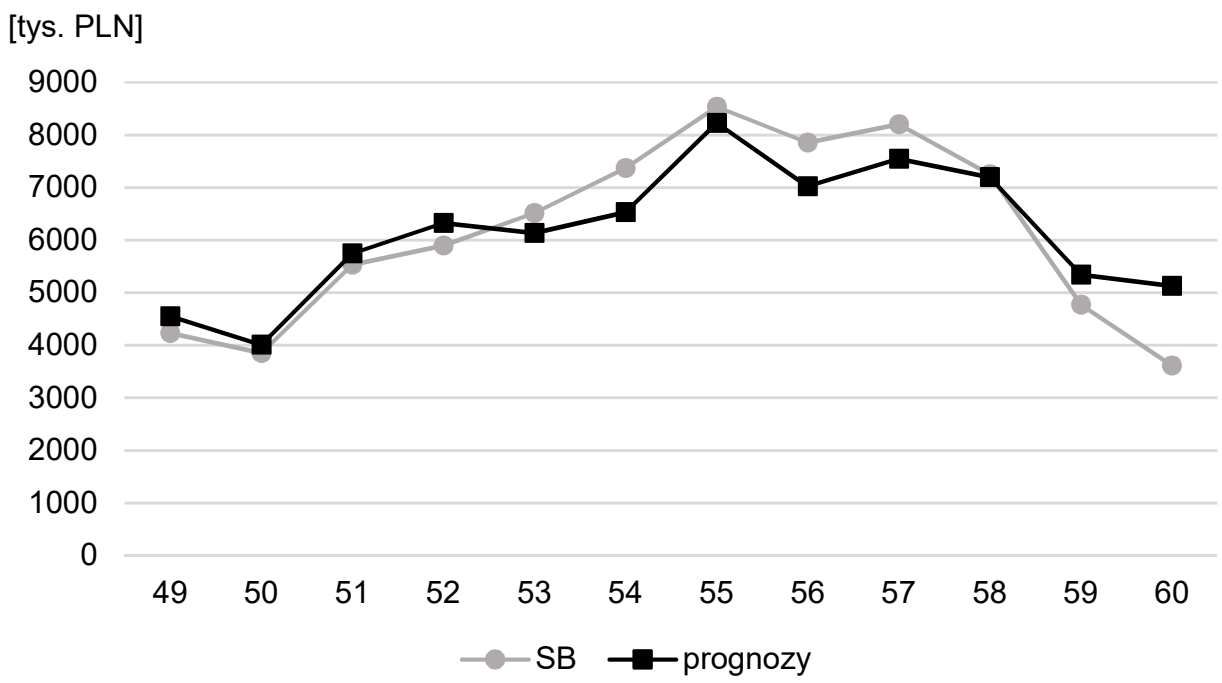

Ryc. 7. Prognozy zmiennej SB wyznaczone na podstawie sieci MLP1

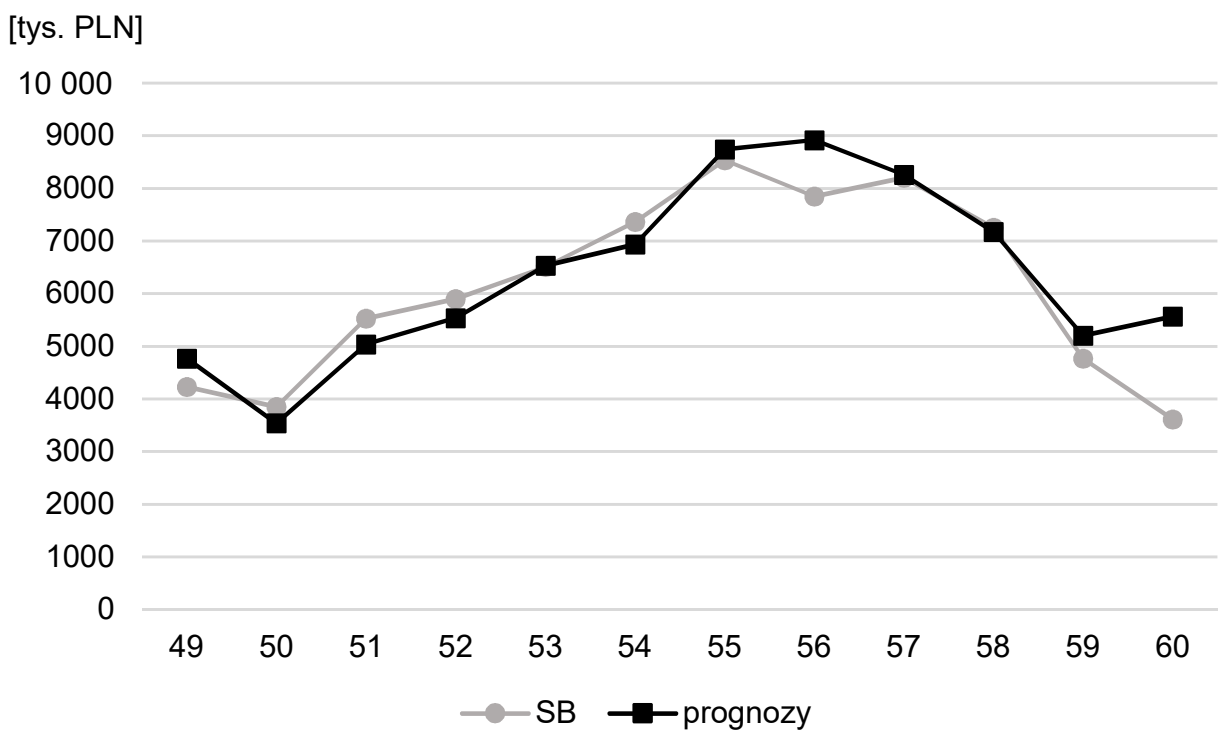

Ryc. 8. Prognozy zmiennej SB wyznaczone na podstawie sieci MLP2

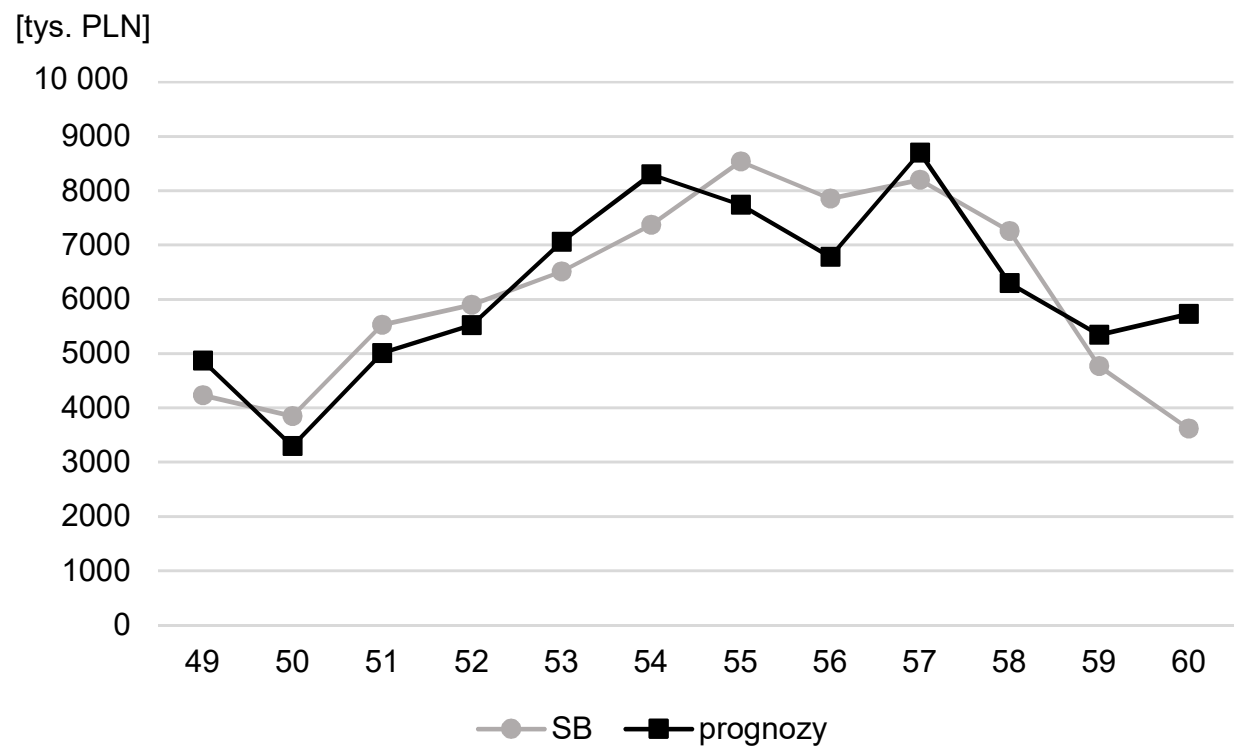

Ryc. 9. Prognozy zmiennej SB (w tys. PLN) wyznaczone na podstawie sieci MLP3 
W tabeli 7 zestawiono średnie absolutne błędy procentowe (MAPE) dla otrzymanych prognoz.

Analizując informacje zawarte $w$ tab. 7 , można zauważyć, że prognozy wartości zmiennej SB, wyznaczone na podstawie zmodyfikowanej metody hybrydowej, charakteryzują się wysoką trafnością, ich błędy ex post wynoszą około $8 \%$ i $9 \%$. Mniejszy błąd otrzymano dla szeregu czasowego podzielonego na trzy frakcje. Prognozy przychodów ze sprzedaży betonu, otrzymane na podstawie modelu neuronowego dla szeregu czasowego bez identyfikacji wzorców, obarczone były naj- większym błędem średnim (większym odpowiednio o ponad 4 pp. i 5 pp.).

Tabela 7. Błędy prognoz [\%] wyznaczonych na podstawie perceptronów wielowarstwowych

\begin{tabular}{|l|c|}
\hline \multicolumn{1}{|c|}{ Numer sieci } & MAPE \\
\hline MLP1-w1 & 9,17 \\
MLP-w2 & \\
\hline MLP2-w1 & 8,05 \\
MLP2-w2 & \\
MLP2-w3 & 13,51 \\
\hline MLP3 & \\
\hline
\end{tabular}

\section{PODSUMOWANIE}

Podział szeregu czasowego na klasy za pomocą samoorganizującej się sieci Kohonena pozwala na wyodrębnienie fragmentów szeregu o podobnych własnościach, co może służyć pogłębieniu jego analizy. Wyróżnione wzorce mogą (ale nie muszą) wykazywać regularność wynikającą z istnienia sezonowości czy tendencji rozwojowej, porównanie ich elementów może też służyć identyfikacji odstających wartości szeregu czy punktów zwrotnych.

Metoda hybrydowa polega na wykorzystaniu wyodrębnionych wzorców do budowy modeli perceptronów wielowarstwowych, na podstawie których można następnie wyznaczać prognozy. Jednak jeśli sekwencja wyodrębnionych frakcji nie powtarza się regularnie, to aproksymacja modelu może być niemożliwa ze względu na zbyt małą ilość wzorcowych wartości wejściowych i wyjściowych niezbędnych do efektywnego nauczenia sieci jednokierunkowej. Metodę hybrydowego modelowania i prognozowania w jej podstawowej wersji powinno się zatem stosować dla bardzo długich szeregów czasowych, w innych przypadkach można wykorzystać zaproponowaną w niniejszym artykule modyfikację.

W przeprowadzonych badaniach empirycznych wyznaczenie modeli perceptronowych dla wyodrębnionych wzorców okazało się niemożliwe, dlatego zmodyfikowano przedstawioną przez Lulę metodę hybrydową. Identyfikację wzorców na podstawie sieci Kohonena przeprowadzono dla danych miesięcznych z kolejnych lat. Dzięki zaliczeniu do tego samego wzorca wartości szeregu z tych samych miesięcy otrzymano powtarzającą się regularnie sekwencję, co umożliwiło budowę modeli perceptronów wielowarstwowych. Prognozy wyznaczone na ich podstawie charakteryzowały się wysoką trafnością, większą niż prognozy otrzymane na podstawie modeli perceptronowych zbudowanych bez identyfikacji wzorców.

\section{PIŚMIENNICTWO}

Dittmann P., Dittmann I., Szabela-Pasierbińska E., Szpulak A. 2009. Prognozowanie w zarządzaniu przedsiębiorstwem. Kraków, Oficyna a Wolters Kluwer Business.

Lula P. 2001. Hybrydowe metody identyfikacji wzorców oraz modelowania i prognozowania szeregów czasowych. Pr. Nauk. AE Wroc. Taksonomia 906, Klasyfikacja i analiza danych - teoria i zastosowania, 68-76. 
Osowski S. 1996. Sieci neuronowe w ujęciu algorytmicznym. Warszawa, WNT.

Perzyńska J. 2018. Zastosowanie sztucznych sieci neuronowych do prognozowania szeregów czasowych. Zesz. Nauk. ZPSB Firma Rynek 2(54), 27-36.

Tadeusiewicz R. 1993. Sieci neuronowe. Warszawa, Akad. Oficyna Wydaw. RM.

Tadeusiewicz R. 1998. Elementarne wprowadzenie do techniki sieci neuronowych z przykładowymi programami. Warszawa, Akad. Oficyna Wydaw.

Witkowska D. 2002. Sztuczne sieci neuronowe i metody statystyczne. Wybrane zagadnienia finansowe. Warszawa, C.H. Beck.

Zawadzki J. 1995. Ekonometryczne metody prognozowania procesów gospodarczych. Szczecin, AR.

Zeliaś A. 2000. Metody statystyczne. Warszawa, PWE.

Streszczenie. W artykule przedstawiono hybrydową metodę budowy modeli szeregów czasowych, z wykorzystaniem sztucznych sieci neuronowych. Ilustracją rozważań o charakterze teoretycznym jest przykład empiryczny, w którym modelowaniu i prognozowaniu poddano zmienną mikroekonomiczną charakteryzującą się występowaniem trendu i wahań sezonowych o silnym natężeniu. W pierwszym etapie badań dokonano identyfikacji wzorców w szeregu czasowym, z wykorzystaniem samoorganizującej się sieci Kohonena. Następnie zastosowano autorską modyfikację metody identyfikacji wzorców i dla wyodrębnionych w ten sposób fragmentów szeregu zbudowano modele perceptronów wielowarstwowych. W ostatnim etapie badań, na podstawie modeli perceptronowych, wyznaczono prognozy; ich jakość oceniono na podstawie średnich błędów ex post. Przeprowadzone badania potwierdziły użyteczność hybrydowych modeli neuronowych w prognozowaniu szeregów czasowych. 